\title{
Europe's Position on the Sino-US Trade Technology Cold War: National Interests and Americanization
}

\author{
Yujia Chen ${ }^{1, *}$ \\ ${ }^{1}$ The Education University of Hong Kong, 10 Lo Ping Road, Tai Po, New Territories, Hong Kong \\ * Yujia Chen, email:827352649@qq.com
}

\begin{abstract}
Since 2018, the Sino-US technology trade war, especially the dispute over Huawei, has had a great impact on the world, especially in Europe.In addition to the Sino-US trade war, under the influence of the US-Europe trade war and SinoEuropean trade friction, European countries' trade technology policies with China are still developing. This article aims to focus on the attitudes of the United Kingdom and 27 EU countries towards the Chinese communications company Huawei, discussing the competition between China and the United States behind technological power and the trade-off between European countries' Americanization and their national interests.
\end{abstract}

Keywords: China, the United States, the European Union, the United Kingdom, Sino-US technology trade war, Americanization, national interests

\section{INTRODUCTION}

Since March 2018, a trade war has erupted between China and the United States (Liu, K.,2018); In the trade war China has been accused of violating market access rules by the United States due to import restrictions, production subsidies from state-owned enterprises, and forced technology transfer. The conflict lasted until January 2020. The two sides reached the "U.S.-China Economic and Trade Agreement" (ETA), marking a new stage of Sino-U.S. trade competition, but this does not mean the end of the conflict (Alicia et al., 2020). In August, the United States announced a ban on tik-tok, a product of Chinese company Bytedance. This is undoubtedly the continuation of the Sino-US science and technology war, which reminds people of the Huawei dispute, the most significant conflict between the two sides in the trade war in the field of science and technology. As a Chinese technology company, Huawei is suspected of stealing American secrets. The Trump administration imposed a local ban on Huawei in early 2018 and arrested Huawei's chief financial officer Meng Wanzhou in December, and the relationship between the two countries fell into tension (Mascitellia \& Chung, 2019).

As we all know, Europe is not only an important economic entity in the world and the most important trading partner of China and the United States, but it is also composed of multiple countries and has research value. China, the United States and Europe will jointly play a leading role in the management of the new world order. Therefore, the main body of this article is Europe rather than other countries. However, it is precisely because Europe is composed of many different countries, each country may have different policy considerations. In addition, the cultural background of Europe as a whole is different from that of China and the United States, and policies are also vulnerable to external influences and changes. Therefore, studying European attitudes in the Sino-US trade war is a difficult problem.

In 2015, scholars such as Federico studied the trade war between China, the United States and Europe.(Caprotti, F.,2015).In 2018, scholars such as Liu studied the process of the Sino-US technological cold war.(Liu \& Woo, 2018) In 2017, scholars such as Jan studied Huawei's influence in Europe. (Jan et al.,2017)In 2019, researchers from CCDCOE conducted research on Huawei's global cybersecurity threats. ( Kaska, K., Beckvard, H., \& Minarik, T.,2019) In 2020, scholars such as Alicia studied Europe's use and worries about Chinese technology.(Alicia et al., 2020) It can be seen from this that although previous scholars have conducted a lot of research on the Sino-US-European trade war and Huawei's influence. However,the existing literature is limited, and fails to conduct a comprehensive and systematic analysis of the combination of Chinese technology represented by Huawei and the reasons and 
results of European countries' benefit selection in the Sino-US technology trade war.

This article will fill the gaps in this field to carefully sort out the attitudes of the UK and 27 EU countries towards the Chinese communications technology company Huawei. This article seeks to discuss the technological competition between China and the United States and the balance of interests between European countries between China and the United States by focusing on Huawei's technology. This is a positive academic significance generated by this research;

In addition, this article also seeks to inspire research on other policy options in related fields through the different trade-offs made by European countries against Huawei in the Sino-US technology war.The research question of this article is how and why the position of European countries on the Sino-US trade technology cold war differ.
In this regard, this article argues that in most cases, Europe's attitude towards Huawei is complicated and changeable, which is related to Americanization and national interests.In order to explore the authenticity of this hypothesis, the article will be divided into five parts,starting with the background and research significance of the Sino-US trade war. The second part is a literature review, looking at the changes caused by the trade war through the study of Sino-US-Europe relations. The next part describes the author's own research theory. The fourth part is to show the evidence and research methods of the article. The next part is the results and discussion section, showing the results of the tables and figures and in-depth analysis. The last part is the conclusion part, which summarizes the article and shows its limitations and possibilities for further research.

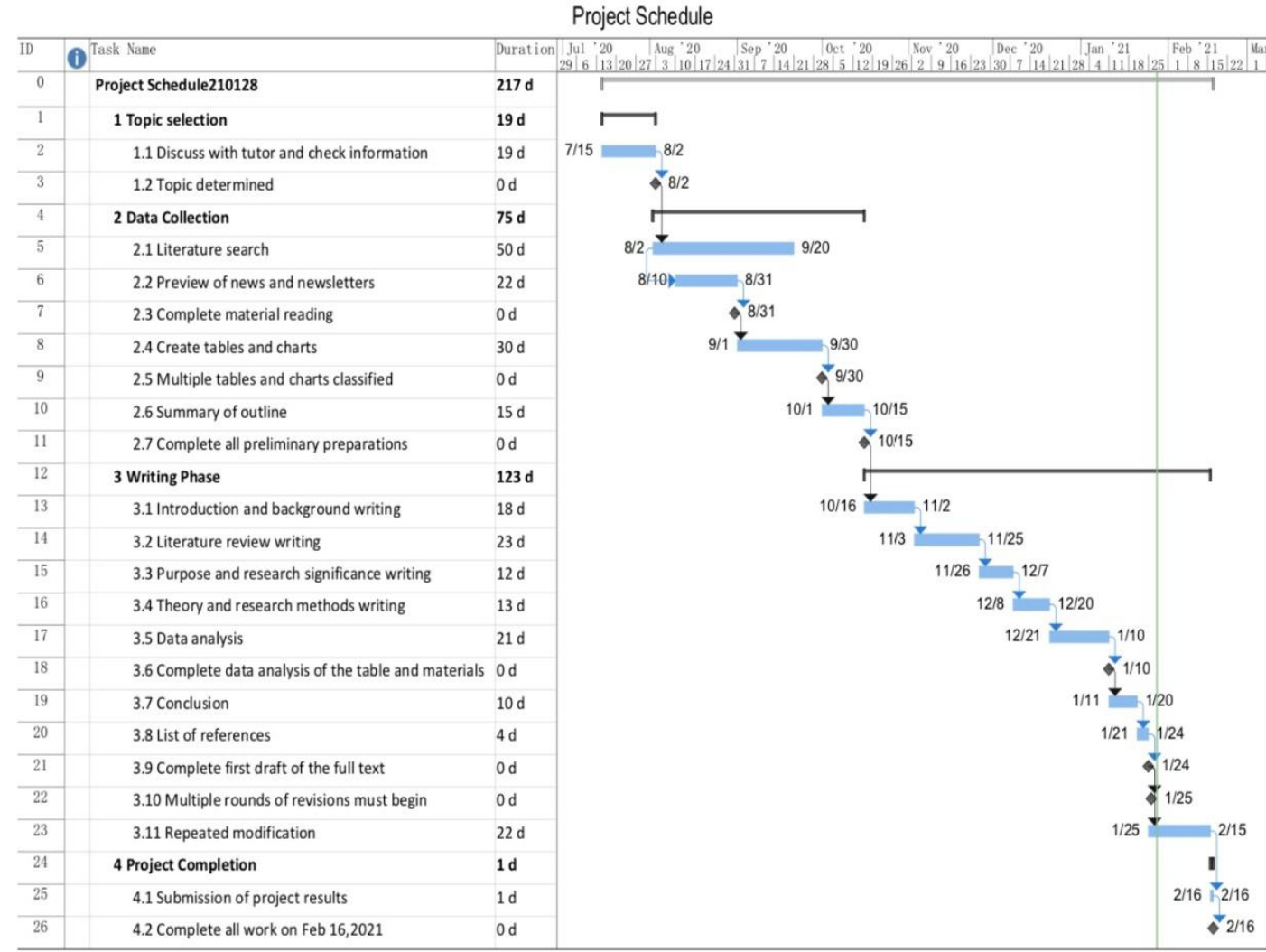

Figure 1 Project Schedule

Source: This figure is organized by the author based on news reports. Please refer to the appendix for details.

\section{LITERATURE REVIEW}

\subsection{Geopolitics and the theory of balance of power}

Geopolitics was first proposed by Kjellen of Sweden in "On the State". After Mahan, Mackinder and Spykman had important developments, it can be summarized as the interaction of geography and technology and its influence on politics and strategy. (Sempa, F. P. ,2002) The research in this article takes Huawei as an example to look at Europe's position in the Sino-US trade war. You can see the impact of technology on European decision-making. At the same time, the article also demonstrates the geographical location of Europe, America and China. 
Economic cooperation. Therefore, geopolitical theory is suitable for the study of this article.

In addition, the modernist expression of geopolitical theory is the theory of power balance. In the concept of American scholar Kenneth Waltz, power balance refers to the fact that all forces are relatively stable and mutually It is a state that no one is willing to break.(Waltz, K. N.,2010) The relationship between China, the United States and Europe is changing due to changes in power, which is also an important reason for Europe to make different policy considerations.

Therefore, this article also uses the theory of power balance to conduct research $(\mathrm{Wu}, 2018)$. Because it is necessary to study the relationship between China, the United States and Europe first by studying the status of the relationship between each other, long-term cooperation or conflict, and using the balance of power theory to see the influence of the two parties on the other.

\subsection{Sino-U.S.-Europe Relations}

\subsubsection{Sino-US relationship}

The first is to study Sino-US relations. Because the subject of this article is to study Europe's position on the Sino-US trade war, studying the development process of Sino-US cooperation and conflicts in the past, we can see the changes in Sino-US relations under the trade war and how this change affects European responses.

The Sino-US relationship is called the most important bilateral relationship.(Zhang, B.,2020) China and the United States went through three periods: from 1949 to the early 1970s, China and the United States engaged in all-out confrontations, such as the Korean War; then, from the normalization of Sino-US relations to the end of 1980, the two sides maintained cooperation against the Soviet Union. Since the 1990s, China and the United States have been in a state of coexistence of cooperation and disputes.(Woon, C.Y.,2018)

In fact, China and the United States have always maintained close cooperation in international security areas such as counter-terrorism such as escort in the Gulf of Aden, comprehensive mutual recognition agreements for civil aviation, and the fight against Ebola virus. However, conflicts often occur between China and the United States, especially in the area of trade. In fact, since China's accession to the World Trade Organization, the rapid development of China's economy has led to an increase in the US trade deficit with China. In 2017, the US-China trade deficit increased to $46 \%$. At the same time, the previous article(Alicia et al., 2020) mentioned that China's production subsidies and import restrictions on local industries made the United States believe that China has implemented the principle of market discrimination to deter foreign companies. For example, China prohibits the use of software such as
Twitter, Google and WhatsApp when installing protective walls. The development of emerging technology industries such as Weibo, Baidu and WeChat that provide the same services.

In addition, the United States also accused China of forcing technology transfer and infringement of intellectual property rights. For example, the United States is considering using China's MC-25 industrial upgrade plan to use WTO-banned policy tools to achieve political goals.(Alicia et al., 2020) The United States has seized the loopholes in the WTO principles in the field of overseas investment. It not only seeks to cooperate with other countries to limit China's foreign investment, but also jointly advocates with other countries to update existing WTO principles to achieve its goals. For the United States, China should be regarded as a threatening competitor, not a strategic partner (Liu \& Woo, 2018).

In this "security dilemma", the United States seeks strategic cooperation with the European Union to counter China. Up to now, no substantial research has been conducted on the balance of power between China, the United States and Europe through the Huawei case, but this research can generate new insights into Sino-US relations: Europe's position in Sino-US trade will be affected by Sino-US relations. The impact will also affect the development of Sino-US relations. This is a balance of power.

\subsubsection{European-American relations}

It is very necessary to show the development process of European-American relations, because Europe's position in the Sino-US trade war will be affected by European-American relations.

In theory, geographical location is an important factor affecting geopolitics and geoeconomics (Wang et al., 2017). The United States and the European Union cross the Atlantic Ocean. From a geographical point of view, they are a natural alliance. At the same time, as the two entities with the highest levels of economic development and political democracy, the United States and the European Union have long had a highly open and mutually beneficial business relationship.

Based on the above reasons, the two parties have established a long-term partnership. From the establishment of NATO in 1949 to the signing of the Transatlantic Declaration in 1995, the scope of transatlantic cooperation between the two parties covered many aspects such as trade, energy and solar defense. (Smith, \& Michael.,2011) But this highly dependent relationship is more likely to cause trade conflicts.

On the one hand, due to trade barriers such as tariffs and production subsidies, the two have often encountered trade disputes in the steel and aerospace fields in recent years, such as the long-term competition between Boeing 
and Airbus. On the other hand, the trade dispute over genetically modified foods and beef hormones shows that there are differences in regulatory methods and social preferences between the United States and the European Union.

At a deeper level, differences in diplomatic strategies have led to deviations in economic and political actions between the United States and the European Union. The EU has long pursued the coordination of internal interests and follows the development of multilateral trade relations under WTO rules. But as the sole superpower, the United States prefers unilateral trade practices to maximize its own interests. In 2018, the European Union proposed the concept of digital taxation for American technology companies. In October 2019, an Airbus ruling made the United States impose tariffs on EU goods. It is not difficult to see that there is a huge difference between the United States and the European Union (Raymond, 2007).

However, geo-culture can resolve conflicts on its own. After the EU made concessions, European-American relations have entered a new phase proposed by the United States: Europe and the United States respectively pledged to buy each other's soybeans and LNG to reduce their dependence on China and Russia (Sotiris, 2018). In order to maintain the balance of power, the EU seeks to develop multilateral relations with other entities, especially China.

So far, there has not been a substantial study on the balance of power between China, the United States and Europe through the Huawei case study, but this study can provide new insights into the relationship between Europe and the United States: The position of Europe in the Sino-US trade war will be affected by the relationship between Europe and the United States, and vice versa.

\subsubsection{Sino-European Relations}

Since the research topic of this article is the role of Europe in the Sino-US trade war, studying the background of Sino-European relations, we can see the positive or negative impact of the trade war on SinoEuropean relations, and then study the European attitude towards Huawei based on the impact. China and Europe belong to the two sides of Eurasia. Although they restored diplomatic relations with important European countries such as Germany and France, they did not deepen their relations in the beginning. It was not until 1985 that the two sides signed the China-EU Trade Cooperation Agreement in 1985, and conducted frequent trade exchanges. Data in the first two quarters of 2020 show that China has surpassed the United States to become the EU's largest trading partner. Unlike the unilateralist strategy of the United States, China and the European Union have similar foreign development strategies, that is, they conduct multilateral diplomacy in accordance with the world's leading trade rules. Driven by this concept, China and the European Union have reached a lot of cooperation. For example, the ChinaEurope summit allowed both parties to promote cooperation in various fields such as trade, education and technology. The withdrawal of the United States from the Paris Agreement seems to imply the success of China and the European Union in combating climate change and cooperation.

As we all know, geo-economic driving forces have promoted the development of economic relations through factors such as networks, technology and industrial policies. China-EU relations have benefited to a large extent from this. The "Belt and Road" policy can not only enable both parties to obtain common economic benefits, but also provide China with technical support to countries along the route, especially the construction of $5 \mathrm{G}$ network bases.

However, in recent years, voices questioning the effectiveness and safety of this policy have gradually appeared in the EU member states of the "Belt and Road" initiative. At the same time, on the one hand, the EU is under pressure from the United States to express dissatisfaction with China's participation in the $5 \mathrm{G}$ construction in Europe. On the other hand, the EU is worried about the possible impact of ETA on it.

So far, there is no substantive research on the balance of power between China, the United States and Europe through the Huawei case, and this research has produced new insights on the relationship between Europe and the United States: Europe's position in the Sino-US trade war will be affected by China-EU relations and will also affect China-EU relations.

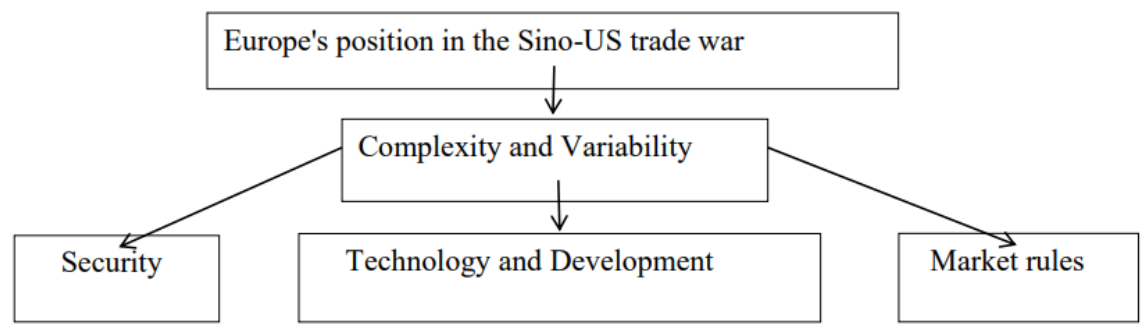

Figure 2 Europe's position in the Sino-US trade war 
Source: This figure is organized by the author based on news reports. Please refer to the appendix for details.

In the previous part, the article obtained new insights into the balance of power between China, the United States and Europe by discussing the relationship between China, the United States and Europe.

In the theoretical part, this article focuses on security, technological development and market rules to study the reasons for different European attitudes towards Huawei. There are three points.

First of all, technology is an important reason for the EU's feedback on the Sino-US technology war. China's technology transfer has enabled China's technological level to leap forward, which has made the European manufacturing industry more efficient, thereby increasing the EU and China's willingness to cooperate in technology. In addition, although ETA may prevent China from fulfilling some of its commitments to the EU, ETA's provisions on the protection of intellectual property rights can benefit the EU (Dadush et al., 2019); secondly, it is the EU's position to maintain market rules. The EU has always pursued trade and multilateral relations on the basis of not violating WTO guidelines. In recent years, the reason why the EU's direct investment in China has declined year after year may be related to China's irregular market access and lack of foreign investment protection (EU Chamber of Commerce in China, 2019). This unfair market environment often arouses the concerns of the EU, but the China-EU Bilateral Investment Treaty (CIA) will make bilateral trade fairer and make the EU more assured that Chinese technology companies such as Huawei will participate in $5 \mathrm{G}$ construction(Alicia et al., 2020) ;

Last but most importantly, maintaining the security of the alliance is always the top priority for the EU. Due to the different political systems between China and the EU, the EU has always been cautious about cooperation with China in sensitive areas. Moreover, the "One Belt, One
Road" plan has caused human rights advocates to worry about whether China has strengthened its control over exporting countries through the export of surveillance technology (Zenglein et al, 2019).So, what is the specific attitude of different European countries towards Huawei? We will discuss in the following parts.

\section{EVIDENCE AND METHODS}

This study uses thematic analysis method. Topic analysis is a method of analyzing qualitative data. It is usually used to identify common topics, themes, central ideas and meanings through data inspection from a text. It can be used to answer some research questions such as survey responses. The most common form includes six steps: Coding, Generating themes, Reviewing themes, Defining and naming themes, and Writing up. Topic analysis has strong flexibility, allowing researchers to have greater flexibility in interpreting data. In addition, by classifying data into various topics, researchers can more easily deal with large-scale data sets(AttrideStirling,2001).This research method not only makes it easier for researchers to analyze European attitudes, but also allows readers to preview them at a glance.

The above method was used in this study. In order to obtain extremely strong timeliness and authenticity, this article retrieves news reports from November 2018 to August 31, 2020, and divides the collected data into two common themes of country and position, and rewrites the latter. It is classified into three themes: security, technology and development, and market rules. The researchers made the data into figures and figures, and found information about the attitudes of European countries in the Sino-US science and technology war through the displayed data, and then combined the information found to conduct a more in-depth background analysis.

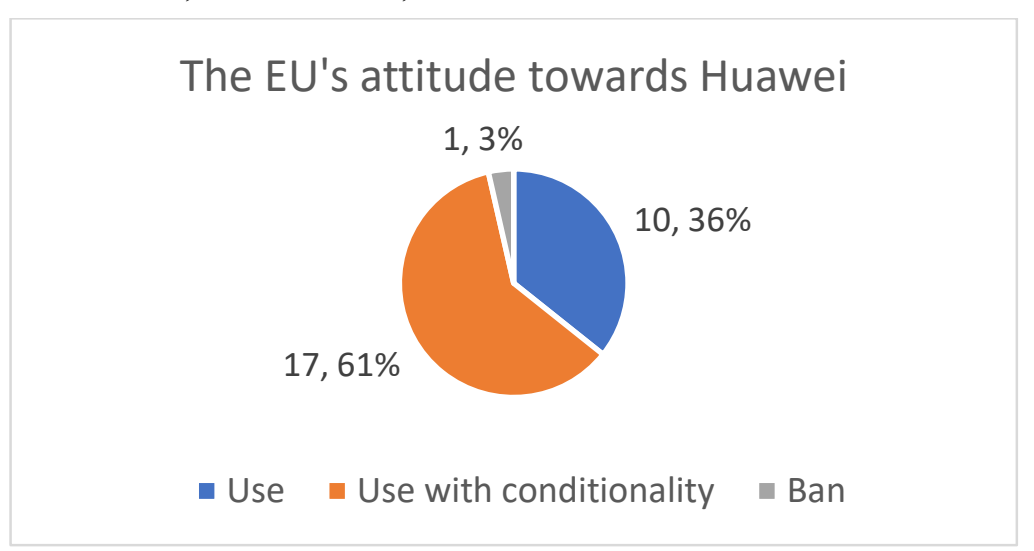

Figure 3 The EU's attitude towards Huawei

Source: This figure is organized by the author based on news reports. Please refer to the appendix for details. 
Table 1. Attitude to Huawei by EU countries

\begin{tabular}{|c|c|c|c|}
\hline $\begin{array}{c}\text { Altitude to Huawei } \\
\text { Use }\end{array}$ & Country Number & Percentage & $\begin{array}{c}\text { Country Names } \\
\text { Belgium,Bulgaria,Cyprus,Cro } \\
\text { atia,Germany,Hungary,Irelan } \\
\text { d,Luxembourg,Malta,Slovakia }\end{array}$ \\
$\begin{array}{c}\text { Austria,Czech } \\
\text { Use with } \\
\text { Conditionality }\end{array}$ & 10 & $36 \%$ & $\begin{array}{l}\text { Repulic,Denmark,Estonia,Fi } \\
\text { nland,France,Greece,Italy,Lat } \\
\text { via,Lithuania,Netherlands,Pol } \\
\text { and,Portugal,Romania,Sloven } \\
\text { ia.Spain,Sweden }\end{array}$ \\
\hline Ban & 17 & $61 \%$ & United Kingdom \\
\hline
\end{tabular}

Source: This table is organized by the author based on news reports. Please refer to the appendix for details.

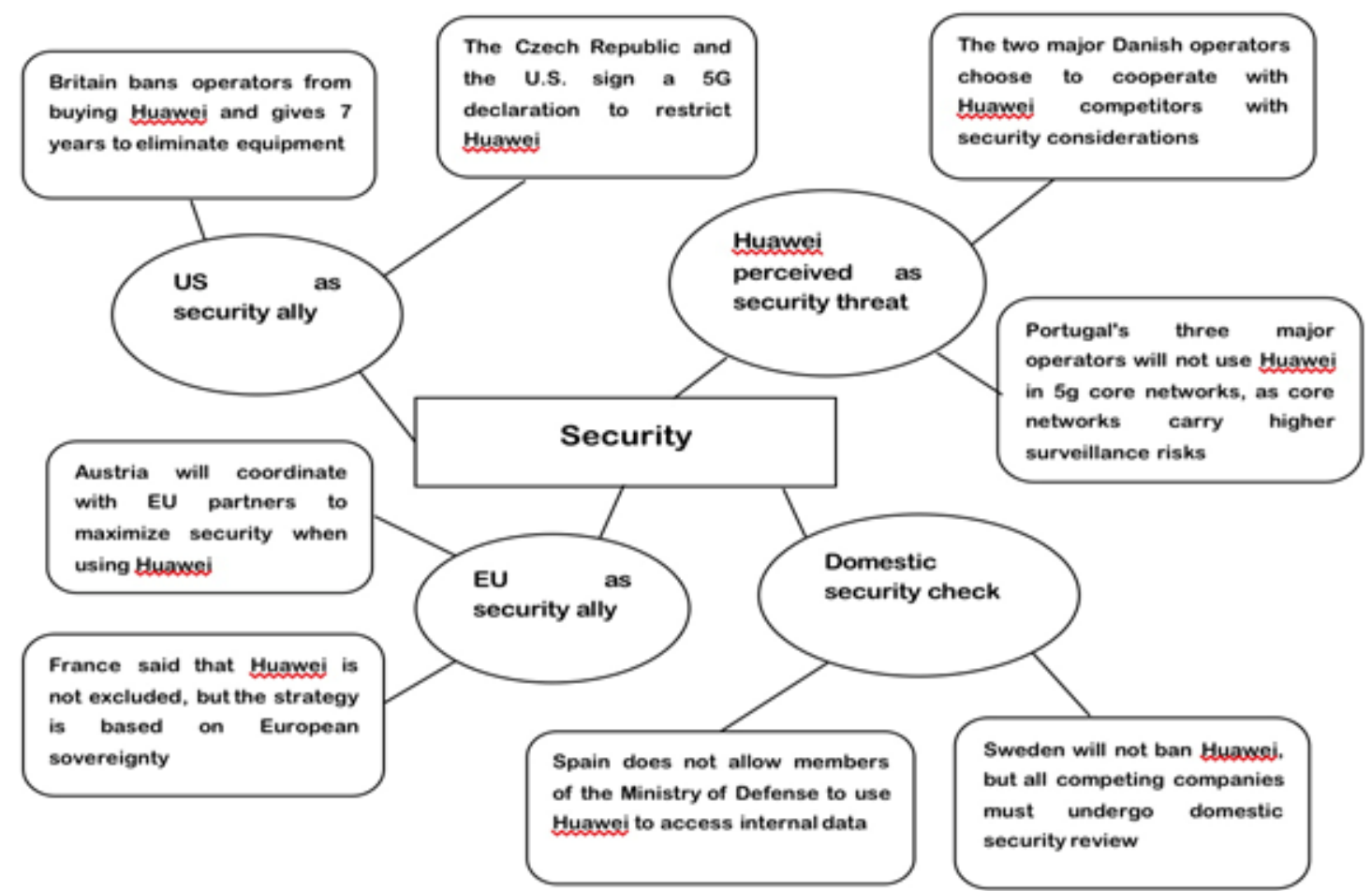

Figure 4 Security Thematic Network

Source: This figure is organized by the author based on news reports. Please refer to the appendix for details. 


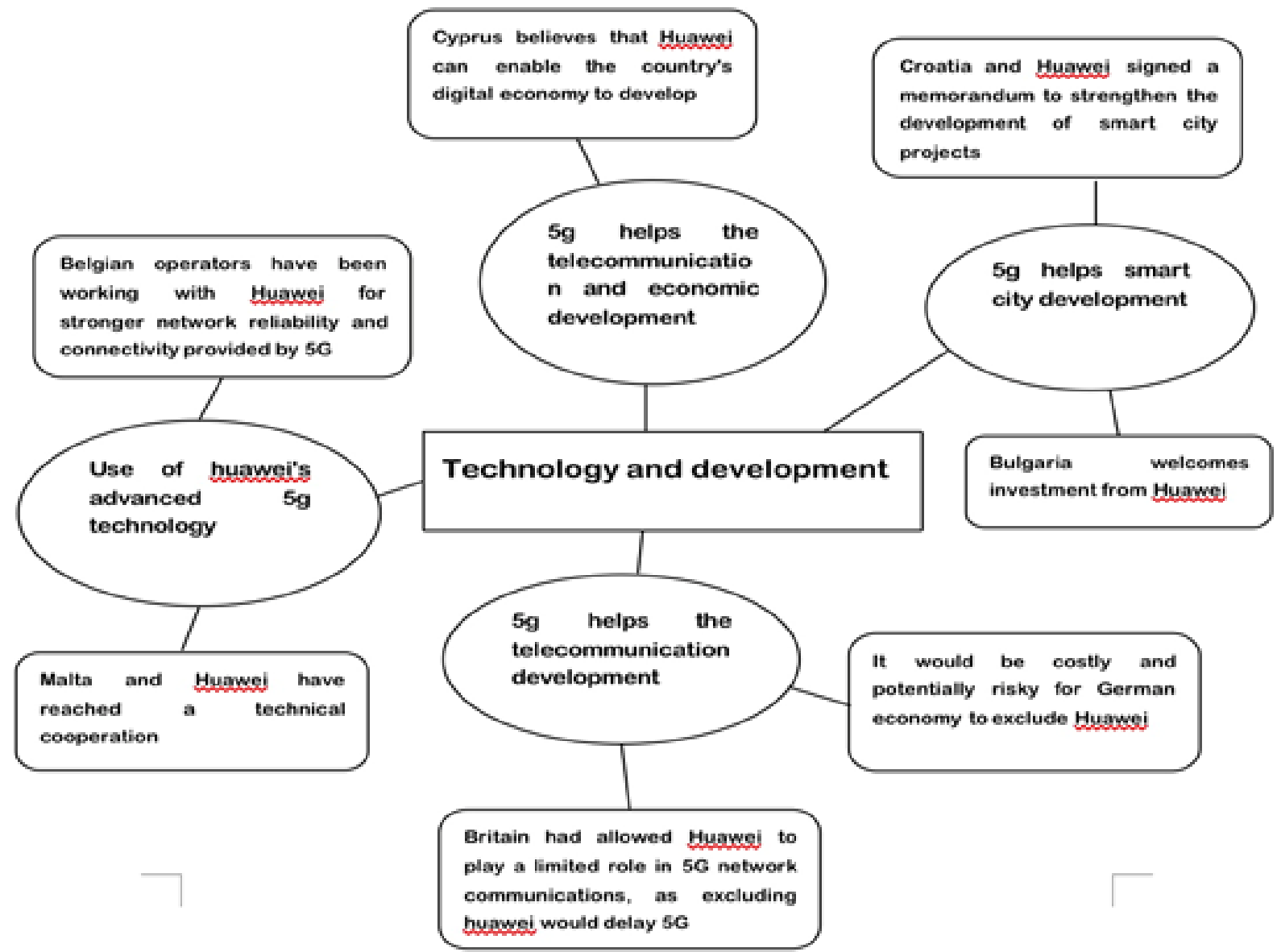

Figure 5 Technology and Development Thematic Network

Source: This figure is organized by the author based on news reports. Please refer to the appendix for details.

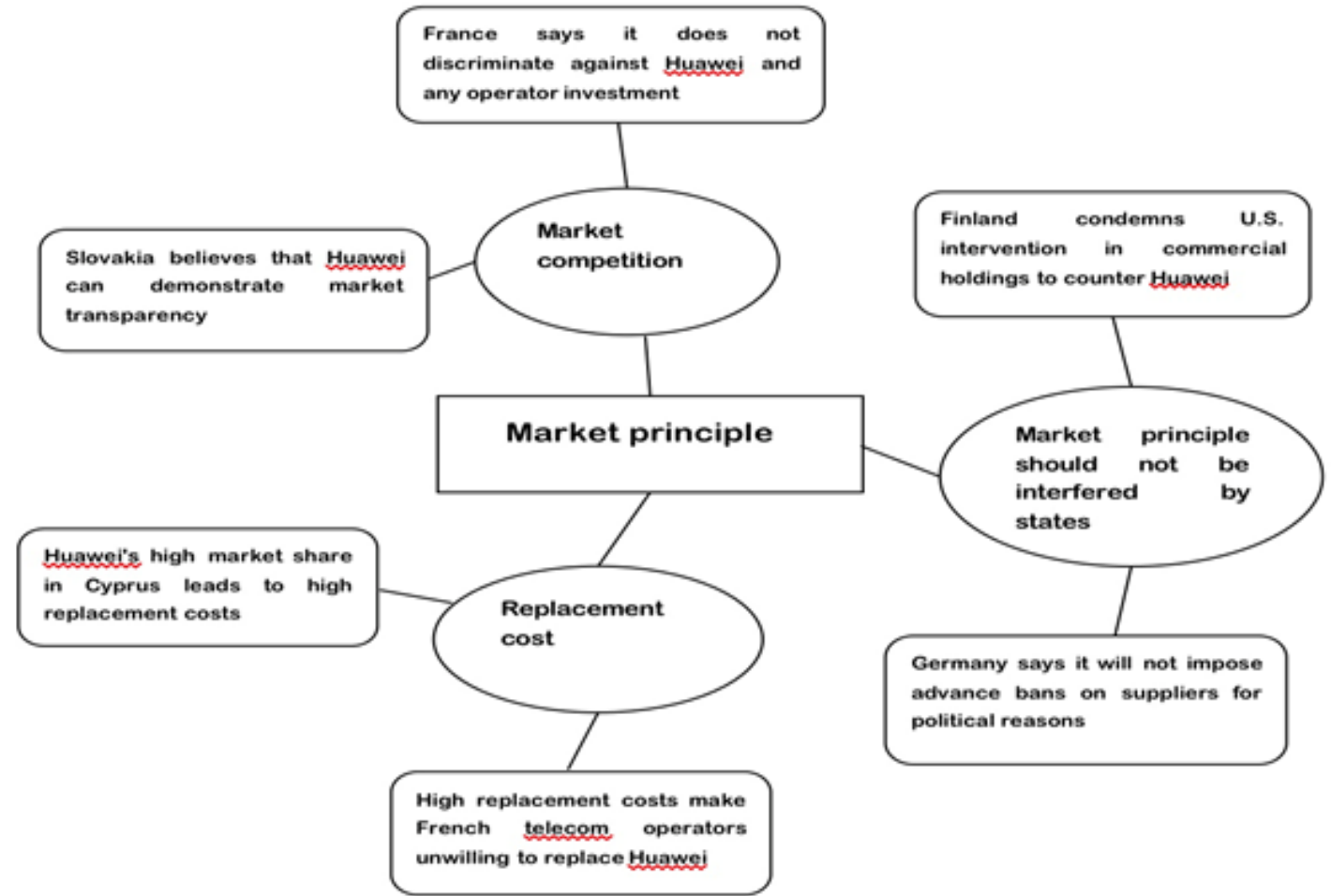

Figure 6 Market Principle Thematic Network

Source: This figure is organized by the author based on news reports. Please refer to the appendix for details. 


\section{RESULTS AND DISCUSSIONS}

\subsection{Brief introduction}

The previous part introduces the evidence and methods of this article, this part will describe the figures and figures and make specific analysis based on the background.

First of all, Figure 3 shows the attitude of the 27 EU countries and the United Kingdom towards Huawei. It can be seen that as of August 31, only 1 country has completely banned the use of Huawei, while the remaining 27 countries have allowed the use of Huawei, of which 17 Several countries stipulate the use of Huawei under certain restrictions.

In addition, Figure 4, Figure 5, and Figure 6 intercept the news reports in the appendix, respectively showing the positions of various countries on Huawei from the three global themes of security, technology and development, and market principles. In Figure 2, the news is divided into four organizational themes: the United States as a security ally, the European Union as a security ally, domestic security review, and Huawei as a security threat. Figure 3 is divided into four organizational themes: Use of huawei's advanced $5 \mathrm{~g}$ technology, 5g's help for electronic communication development, $5 \mathrm{~g}$ 's help for economic development, and $5 \mathrm{~g}$ 's help for smart city development. Figure 5 is a secondary classification from the three organizational themes of Market competition, Replacement cost, and Market principle should not be interfered by states.

Combined with Figure 3 and the appendix, Belgium, Bulgaria, Cyprus, Croatia, Germany, Hungary, Ireland, Luxembourg, Malta and Slovakia Actively use Huawei. Austria, the Czech Republic, Denmark, Estonia, Finland, France, Greece, Italy, Latvia, Lithuania, the Netherlands, Poland, Portugal, Romania, Slovenia, Spain and Sweden choose to use Huawei conditionally. The UK is the only country in the data selection that completely bans the use of Huawei.

From Figure 4, Figure 5, and Figure 6 and the appendix, Belgium, Malta, Croatia, and Bulgaria argues that Huawei's 5G technology will help the country's use and the construction of smart cities. Moreover, Hungary, Luxembourg, Slovakia, Ireland, and Italy argues that as a supplier,Huawei should be allowed to participate fairly in domestic 5G bidding, but Telecom Italia later announced that Huawei was excluded from core network construction due to a competitive disadvantage. For Cyprus and Germany, for the development of $5 \mathrm{G}$ technology and the principle of fairness in the market, these two countries prefer to use Huawei

At the same time, the United Kingdom, the Czech Republic, Estonia, Latvia, Poland, Romania, Slovenia, and Lithuania have all signed $5 \mathrm{G}$ security alliance agreements with the United States. Among them, the Czech government has experienced repeated changes from banning Huawei to restrictive use of Huawei, and argues that Huawei is safe. After the threat, it said that Huawei could compete in a fair market environment and finally seek to reach an agreement with the EU on a solution. The United Kingdom is the only country in statistics that completely bans the use of Huawei. It has also experienced fluctuations from partial use to prohibition.And Lithuania is also obeying EU resolutions while monitoring Huawei's security threats. For Estonia, the new regulations allow them to restrict the use of Huawei under the pressure of market principles such as high equipment replacement costs. Latvia has also signed a 5G memorandum of understanding with China in consideration of Huawei's development of $5 \mathrm{G}$ technology in the country.

Regarding the use of Huawei, Austria seeks to maximize its agreement with the European Union. France is a loyal supporter of the EU resolutions and hopes that it will not discriminate against any operators such as Huawei while respecting market rules. Portugal, Spain, Sweden, Greece and Denmark all regard safety as their primary consideration. Among them, Portugal, Greece and Denmark are all worried about Huawei's potential security risks, but Portugal seeks fair competition from any supplier, while Denmark argues that it is safer to cooperate with operators within the EU. Spain and Sweden are pursuing the use of Huawei while avoiding risks internally. The Netherlands seeks to filter risks through internal security checks while reaching a $5 \mathrm{G}$ technical cooperation with Huawei.

\subsection{Background analysis}

The content of the figure is briefly described above, and then select key countries to conduct an in-depth background analysis of the reasons for their attitudes toward Huawei.

\subsubsection{United Kingdom}

Britain's attitude towards Huawei is mainly due to Britain's Brexit and the alliance between Britain and the United States. First of all, geopolitically, the United Kingdom is an island country with a long democratic system, which determines that the United Kingdom itself has enough capacity to support the country and has long been full of voices against the European Union. The subsequent immigration issues and economic crisis made EU supporters in the UK realize that the UK is being absorbed by the EU. In addition, China has had a huge impact on the world market over the years after its accession to the World Trade Organization, such as occupying production markets such as steel. However, the EU still argues defensive measures instead of actively challenging China, which is the opposite of the British policy towards China. (Riley, A., \& Ghilès, F., 2016) 
In addition, the United Kingdom is a member of the Five Eyes Alliance,which maintains consistent policy actions on intelligence sharing and data security. In dealing with Huawei technology, the Five Eyes Alliance argues that China's 5G technology represented by Huawei lacks supervision and lacks transparency. Therefore, many members such as the United States have implemented a Huawei ban, while the United Kingdom has also turned from an initial open attitude to prohibiting the use of Huawei when security agencies are opposed to Huawei.

It can be seen from the above that due to deviations from the EU's overall development direction including its China policy and as a member of the pro-American Five Eyes Alliance, it is foreseeable that the UK will ban the use of Huawei. (Oxford Analytica, 2019)

\subsubsection{Germany}

It can be seen from figures and figures that Germany has a relatively positive attitude towards Huawei, which is mainly due to the close technical cooperation between China and Germany. Since China's accession to the WTO, China and Germany have maintained economic cooperation for a long time. China and Germany formed an alliance in the fourth industrial revolution. In 2015, the two countries reached a memorandum of understanding, which will focus on Industry 4.0, which is the standardization of intelligent manufacturing technology, including cooperation in sharing knowledge, artificial intelligence and communication services. (Nicoletta Corrocher et al, 2020) Deutsche Telekom, which cooperates with China's 5G, covers two-thirds of Germany's population.

In addition, in 2018, the mayor of Duisburg visited Huawei's headquarters and designated Duisburg as a smart city driven by $5 \mathrm{G}$ technology in China. In fact, China's rapid increase in the Sino-German value chain, foreign capital controls, and European defense policies have also caused the German trade unions (BDI) to question and worry about current cooperation.(Glowik, M. ,2020)

However, on the one hand, China has replaced the United States as Germany's largest trading partner in recent years, and German companies have made huge profits from China. On the other hand, for Germany, the profits brought about by the US replacing China are more risky. Based on the consideration of safeguarding German interests, the conservative Merkel government tends to maintain the status quo and strengthen cooperation with China. (Barkin, N.,2020) Therefore, Germany currently holds a position of using 5G technology represented by Huawei.

\subsubsection{Cyprus, Hungary, Bulgaria, Croatia, Slovakia and Malta}

It can be seen from the figure that these countries have relatively positive attitudes towards Huawei, mainly because these countries are positively affected by the "The Belt and Road Initiative" (BRI). China proposed the BRI policy in 2013, aiming to provide resources to countries along the route to help them build infrastructure and strengthen exchanges between countries. EU countries including Bulgaria have also become the first countries to support the BRI initiative. Since the launch of the plan, China's long-term free trade and huge investment have achieved certain results, mainly in the improvement of infrastructure, especially cross-border transportation and transportation infrastructure, such as Plovdiv Airport in Bulgaria and the Hungary-SerbiaPiraeus Reconstruction and expansion of Railway. (Deng, F.,2020) In addition, with the development of the "Digital Silk Road" project, China has also produced technology spillovers to these countries. For example, Slovakia, Croatia and other countries signed the "Future Seeds" plan with Huawei, Malta and Huawei The signed smart city project and the "Saint Sophia" high-tech smart city project signed by Bulgaria and ZTE. (Matthew Vella,2019) Therefore, in the case of BRI assistance Basically, these countries have a positive attitude towards Chinese technologies such as Huawei.

In fact, other countries within the EU that support BRI also have relatively different tendencies. For example, Portugal, the Netherlands, and Italy are more optimistic about the future development of the BRI initiative. In contrast, France, Belgium, and Ireland are more optimistic about the BRI economy. Expectations for development are relatively negative. However, compared with the first batch of BRI countries listed above, these countries have a relatively strong economic foundation and are less dependent on BRI assistance. (Alicia et al.,2020) Therefore, when expressing their attitudes towards Huawei, these countries are not the same, and it is difficult to generalize.

\subsubsection{Czech Republic}

In 2018, shortly after the Czech National Network and Information Security Agency warned Huawei of security problems and Czech Prime Minister Andrej Babis announced that Huawei equipment was withdrawn from government offices, Andrej Babis turned to say that certain departments do not represent the government's position and Czech President Milos Zeman has repeatedly expressed his support for Huawei. This change in the attitude of the Czech government towards Huawei is related to its personal political bias. (Albright et al,2020)

In fact, Czech President Milos Zeman is considered to be a pro-China man. He once appointed Ye Jianming, 
chairman of CEFC China Energy, as his economic adviser. Besides,He also caused doubts in Czech society due to criticisms of NATO, Czech intelligence agencies and Tibetan independence. Therefore, his attitude towards Huawei is relatively positive.(Ogrodnik \& Łukasz,2019)

However, unlike Milos Zeman, the Czech Prime Minister belongs to the Communist Party, but he has also been regarded by some as a supporter of the transatlantic system for criticizing CEFC China Energy and visiting the United States in 2019 to discuss cybersecurity issues. In fact, judging from the change in his attitude towards Huawei, he is closer to a pragmatist. Therefore, his attitude towards China's Huawei technology is more neutral. (Polyakova, A., et al, 2019)

In addition, in 2020, Milos Zeman and Milos Zeman opposed the visit of the President of the Czech Senate, Miloš Vystrčil, to use "provocation" and "confusion of politics and business" respectively. According to the statement, combined with the different attitudes of other government officials in the Czech Republic, it can be seen that the Czech government's stance on China is quite different, which seriously affects its attitude towards Huawei. Although the Czech Republic has restricted the use of Huawei as of the date of data collection, it is more because of the commercial status that the later changes are unpredictable. (Wang Qi,2020)

From the above background analysis combined with the previous figure analysis, it can be seen that although the EU is a whole, internal members consider factors It is still based on the domestic situation. Some countries with stronger economies, such as the United Kingdom, argues that they can make independent decisions and develop better when they leave the EU. Some countries that are biased towards Americanism will agree more with the American Union than with the European Union. Other countries may have long-term close cooperation with China and will consider their relationship with China. The different political situations in some countries may cause repeated fluctuations in decision-making opinions, while the remaining countries without serious political biases will consider more to be consistent with the overall opinion of the EU. Therefore, it can be well explained why when faced with a number of policy issues such as whether to use Huawei, the countries within the EU are not consistent but divergent.

\subsection{Result}

From the above analysis, it can be concluded that national interests and Americanism have largely affected the position of EU countries on Huawei. Through the observation of the data and the background analysis, it can be seen that the countries that use Huawei the most actively take into account the assistance of Huawei's 5G technology to the development of domestic electronic communications and smart cities. These countries are not ignorant of the external impact of the political and economic struggles between China and the United States, but they have good expectations for the future of the BRI policy, and compared to the United States, they rely more on China's investment assistance, and objectively speaking, economic Smaller countries are more likely to be helped by China and are more willing to support Huawei.

In addition, the countries with the largest proportion have a neutral and changeable attitude towards Huawei. These countries will basically take into account the three factors of market rules, safety and technology, but their internal situations are different. Only out of national interest considerations, some countries, considering market factors such as replacement costs and the application requirements of Huawei's 5G technology, will choose to conduct internal security checks to eliminate supplier risks in advance instead of completely removing Huawei from the national $5 \mathrm{G}$ network construction.And these countries also often seek to be consistent with the EU's opinions; another part of the countries that have formed a security alliance with the United States or are under pressure from the United States will take security as the primary consideration and choose to replace Huawei with other suppliers or exclude Huawei from the core network construction .

Generally speaking, for the issue of $5 \mathrm{G}$ construction, national interests are the starting point for most EU countries to consider, but the focus is different. Some countries with a weak sense of Americanism argue that Huawei does not pose a major threat to the country's security interests, and that Huawei's 5G technology has a positive impact on the country's current and future development far greater than the effect of replacing Huawei; they argue that Huawei technology poses a security threat to the country. And driven by Americanism, they agree that the current loss of replacing Huawei is less than the possible consequences of continuing to use Huawei. This consequence may include loss of information security and political and economic risks that are at odds with the United States.

From the above, national interests and Americanism greatly affect the attitudes of EU countries towards Huawei. Among them, national interest is the primary influencing factor, which almost determines the direction of attitude, and for some countries, Americanism is also a factor that affects future national interests. EU countries' stance on Huawei also affects their national interests and their relations with the United States. Therefore, for EU countries, the issue of whether and how to use Huawei is affected by economic expectations and the interaction between the two countries. This is a question that needs to weigh the pros and cons from external influences and internal interests.(Tai, W. P., \& Huang, Y. F. ,2018) 


\section{CONCLUSION}

The previous part described the attitudes of the $27 \mathrm{EU}$ countries and the United Kingdom towards Huawei as shown in figures and figures, and selected the background information of key countries for in-depth analysis to explore the specific reasons for this position. As of August 31, 2020, 10 EU countries are actively using Huawei, 17 countries are using Huawei conditionally, and the United Kingdom has imposed a ban on Huawei. Proceeding from the three aspects of security, technology and development, and market regulations, combined with background analysis, the reasons are derived. This is mainly due to the alliance between the country and the United States, the variability of the political orientation of the country's domestic ruling party, and the country's positive influence from China.

To summarize the full article, the EU's position in the field of science and technology in the Sino-US trade war is not static, but a balance of interests based on actual conditions, which is complex and changeable. This also confirms the view of this article: During the technological cold war, Europe's attitude towards Huawei was indeed affected by domestic interests and Americanism.

This research has achieved important research results. First of all, from the full article, the research focus is on Huawei, which explores the European position of Europe in the Sino-US trade technology war. Previous scholars rarely involved this kind of research thought, but this article fills up the gap in this field. In addition, combining the topic summary table and text analysis methods can make the article's thinking more clear and reasonable.

However, this article also has limitations. First of all, this research mainly selects information from news reports for a period of time when summarizing the figures. However, due to the variability of policies, the search method of this research has a certain degree of lag and single. Secondly, due to space limitations, when conducting a background analysis of the reasons for the EU's attitude towards Huawei, only key countries were selected for generalization. In fact, the specific conditions of each country are different. Therefore,this study is partially representative. Finally, the analysis method of this study is based on thematic analysis, so there is a certain degree of subjectivity. In order to improve these shortcomings, we should conduct longitudinal research, expand data collection channels, and rationalize information resources in order to better conduct further research.

\section{APPENDIX I}

Since there is 15-page limitation, I only show part of tables. In case of interest of all tables, please contact the author directly.

Table 2. Global Theme of Security

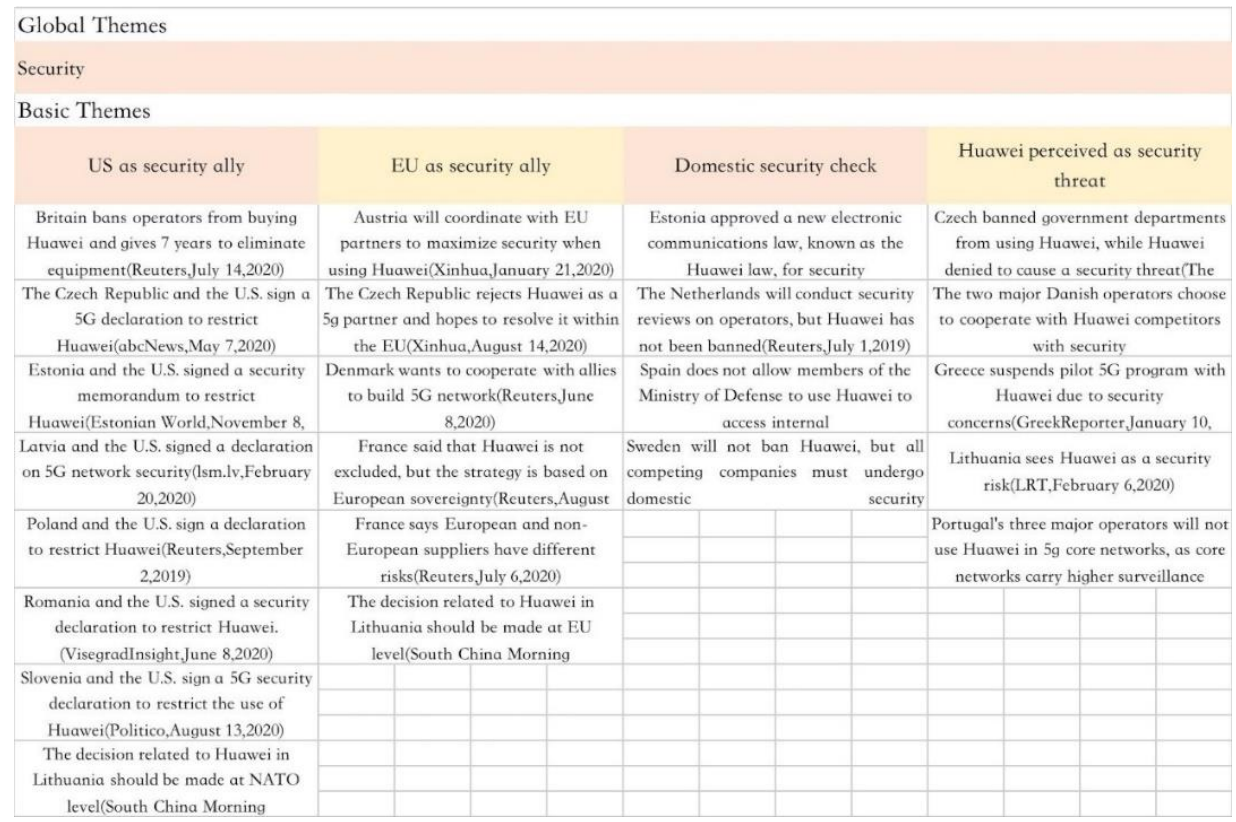

\section{APPENDIX II}


Table 3. Global Theme of Technology and Development

Global Themes

Technology and development

Basic Themes

Use of huawei's advanced $5 \mathrm{~g} \quad 5 \mathrm{~g}$ helps the telecommunication $\quad 5 \mathrm{~g}$ helps the telecommunication technology development and economic development

Belgian operators have been working Britain had allowed Huawei to play a Cyprus believes that Huawei can enable Bulgaria welcomes investment from with Huawei for stronger network limited role in 5G network the country's digital economy to Huawei(Southern Metropolis reliability and connectivity provided by communications, as excluding huawei develop(Financial Mirror.July 18,2020) Daily,October 27,2020)

Dutch telecom operators and Huawei It would be costly and potentially risky have reached a $5 \mathrm{G}$ cooperation for German economy to exclude agreement. (Ttelecom Review,April 30 Huawei.(Reuters,February11,2020) French operators hope to continue cooperation with Huawei on $5 \mathrm{G}$ technology(Reuters,February 20,2020) An operator in Latvia has signed a $5 \mathrm{G}$ memorandum of understanding with Huawei(lsm.lv,February 20,2020) Malta and Huawei have reached a technical cooperation(maltatoday,May

\section{APPENDIX III}

Table 4. Global Theme of Market Principle

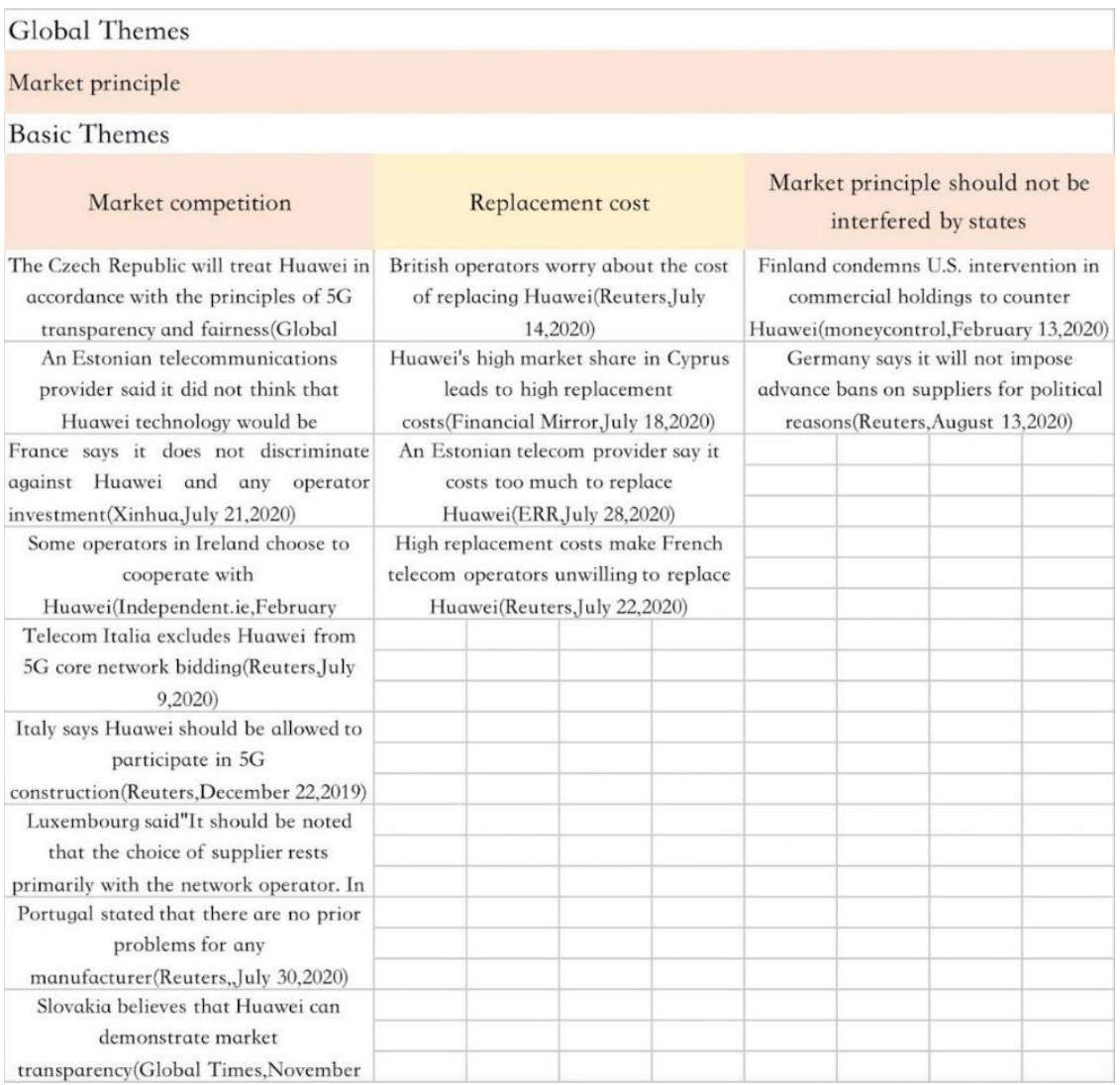




\section{REFERENCES}

[1] Ahearn, R. J. . (2006). Trade conflict and the u.s.european union economic relationship [updated April 11, 2007 ]. Congressional Research Service Reports.

[2] Albright, M., Stoltenberg, N. S. G. J., \& Minister, T. F. (2020). Czech Reservations.

[3] Alicia, G-H., Guntram, W., \& Jianwei, X., Nicolas, P. (2020) EU-China trade and investment relations in challenging times. European Parliament. DOI:10.2861/049101

[4] Attride-Stirling, \& J. (2007). Thematic networks: an analytic tool for qualitative research. Qualitative Research, 1(3), $385-$ 405.DOI:10.1177/146879410100100307

[5] Barkin, N. (2020). Germany's Strategic Grey Zone with China. Carnegie Europe. Available at: https://carnegieeurope. eu/2020/03/25/germany-sstrategic-gray-zone-with-china- pub-81360 [Accessed on 21 September 2020].

[6] Caprotti, F. (2015). Golden sun, green economy: market security and the US/EU-China 'solar trade war'. Asian Geographer, 32(2), 99-115.

[7] Dadush, U., Marta Domínguez-Jiménez, \& Gao, T. . (2019). The state of china-european union economic relations. Working Papers.

[8] Deng, F., Wang, Y., Li, Z., \& Liang, X. (2020). China's Technology Spillover Effects in the Countries along the Belt and Road-Evidence from 49 BRI Countries. Applied Economics, 52(51 ), 5579-5594.

[9] Drahokoupil, J., McCaleb, A., Pawlicki, P., \& Szunomár, Á. (2017). Huawei in Europe: strategic integration of local capabilities in a global production network.

[10] European Union Chamber of Commerce in China. (2018). European Business in China Position Paper 2018/2019.Available

at https://static.europeanchamber.com.cn/upload/docu ments/documents/Executive_Position_Paper_2018 201 9[659].pdf

[11] Glowik, M. (2020). Market Entry Strategies of Huawei in Germany and the Russian Federation from a Network Theory Perspective. In Huawei Goes Global (pp. 11-35). Palgrave Macmillan, Cham.

[12] Kaska, K., Beckvard, H., \& Minarik, T. (2019). Huawei, $5 \mathrm{G}$ and China as a security threat. NATO Cooperative Cyber Defence Center for Excellence (CCDCOE), 28.
[13] Liu, K. (2018). Chinese manufacturing in the shadow of the China-US trade war. Economic Affairs, 38(3), 307-324.

[14] Mascitelli, B., \& Chung, M. (2019).Hue and cry over Huawei: Cold war tensions, security threats or anti-competitive behaviour? Research in Globalization, DOI:10.1016/j.resglo.2019.100002

[15] Matthew Vella. (2019). Huawei link to China carries risk in Safe City Malta project, says US official.Maltatoday.Retrieved from https://www.maltatoday.com.mt/news/national/949 27/huawei_link_in_safe_city_carries_risk\#.YBaJU y276CU

[16] Nicoletta Corrocher, Roberto Mavilia \& Melissa Giorgio (2020) The Sino-German alliance for the fourth industrial revolution: dynamics and policy implications, Journal of Economic Policy Reform, 23:4, 426-446, DOI: $10.1080 / 17487870.2018 .1547639$.

[17] Ogrodnik, Ł. (2019). Czech Republic on the Challenges in Cooperation with China.

[18] Oxford Analytica (2019), "Divergence on Chinese 5G strains'Five Eyes' alliance", Expert Briefings.https://doi.org/10.1108/OXANDB244222.

[19] Polyakova, A., Taussig, T., Reinert, T., Kirişci, K., Sloat, A., Kirchik, J., ... \& Kenealy, A. (2019). The anatomy of illiberal states: assessing and responding to democratic decline in Turkey and Central Europe. Foreign Policy at Brookings.

[20] Riley, A., \& Ghilès, F. (2016). Brexit: causes and consequences. Notes internacionals CIDOB, 159, 14.

[21] Sempa, F. P. (2002). Geopolitics: from the Cold War to the 21st Century. Transaction Publishers.

[22] Serbos, S., \& Anastasiadis, G. (2018). Revisiting europe's geopolitical landscape after the ukraine crisis: america's balance of power strategy. UNI Discussion Papers, 46(46).DOI: 10.5209/RUNI.58378

[23] Smith, \& Michael. (2011). European responses to us diplomacy: 'special relationships', transatlantic governance and world order. Hague Journal of Diplomacy, 6(3), 299-317.

[24] Tai, W. P., \& Huang, Y. F. (2018). Political and economic relationships between China and the Philippines under the OBOR initiative. The Chinese Economy, 51(4), 356-369. 
[25] Tao Liu \& Wing Thye Woo (2018): Understanding the U.S.-China Trade War, China Economic Journal. DOI: $10.1080 / 17538963.2018 .1516256$

[26] Waltz, K. N. (2010). Theory of international politics. Waveland Press.

[27] Wang Qi(2020).Czech President slams senate leader's Taiwan trip, easing tensions with Chinese mainland.Global Times.

[28] Wang, Shufang, Xue, Xiao, Zhu, \& Axing, et al. (2017). The key driving forces for geo-economic relationships between china and asean countries. Sustainability.
[29] [29] Woon, C. Y. (2018). China's contingencies: Critical geopolitics, Chinese exceptionalism and the uses of history. Geopolitics, 23(1), 67-95.

[30] Zhang, B. (2020). Understanding changes in SinoUS relations from a historical perspective. China International Strategy Review, 2(1), 1-13.

[31] Zenglein, M. J., \& Holzmann, A. (2019). Evolving made in China 2025. MERICS Papers on China, (8), 78.

[32] Zhengyu, W. (2018) Classical geopolitics, realism and the balance of power theory, Journal of Strategic Studies, 41:6, 786-823. DOI: $10.1080 / 01402390.2017 .1379398$ 